\title{
BRING IN THE BALLERINAS - A MULTIMODAL ANALYSIS BASED ON THE ACTOR-NETWORK THEORY
}

\section{QUE ENTREM AS BAILARINAS - UMA ANÁLISE MULTIMODAL BASEADA NA TEORIA ATOR-REDE}

Luiz Antônio Caldeira Andrade ${ }^{1}$

Sônia Maria de Oliveira Pimenta²

\begin{abstract}
The aim of this article is to investigate how the physical and non-physical elements in Zach Gross's short video contribute to represent the main female character, Tatyana, around which the story takes place. The video shows two ballerinas at the Metropolitan Opera House performing a scene of Onegin, a Tchaikovsky's opera, based on Pushkin's classical literary work that bears the same name,The study is theoretically and methodologically built on the actor-network theory (ANT) and multimodal analysis as defined in Banks (2015). The main point was to show how the networking of human and non-human objects, including the body itself, takes place across physical and virtual spaces in the expression of the self.
\end{abstract}

KEYWORDS:Actor-Network Theory(ANT). Identity construction. Self. Multimodality.

RESUMO: O objetivo desse artigo é investigar como os elementos físicos e năo físicos no vídeo de Zach Gross contribuem para representar a principal personagem feminina, Tatyana, em torno da qual se desenvolve o enredo. O vídeo apresenta duas bailarinas no Metropolitan Opera House executando uma cena de Onegin, uma ópera de Tchaikovsky, baseada na obra clássica de Pushkin, a qual leva o mesmo nome $O$ estudo é teórica e metodologicamente apoiado na teoria ator-rede (TAR) e no modelo multimodal definido em Banks (2015). O ponto principal foi mostrar como o entrelaçamento de objetos humanos e năo humanos na construçăo de rede, incluindo o próprio corpo, ocorre através de espaços físicos e virtuais na expressăo do eu.

PALAVRAS-CHAVE: Teoria Ator-Rede (TAR). Construçăo identitária. Eu. Multimodalidade.

1 Belo Horizonte, Minas Gerais. Doutor em Linguística do Texto e do Discurso pela Universidade Federal de Minas Gerais. E-mail: lacatc@gmail.com

2 Doutora em Linguística Aplicada e Estudos da Linguagem. E-mail: soniapimenta1@gmail.com 


\section{INTRODUCTION}

The advent of the Digital Revolution in the second half of the $20^{\text {th }}$ century would redefine major concepts such as self. Up to that time self was a concept that belonged to the realm of Psychology, being related to selective memory retrieval, as in Bruner (1994), for instance. However, whether the concept was taken as exclusively belonging to the domains of Philosophy and Psychology, it would, then, begin to be investigated by other socially-driven fields, such as Sociology, Anthropology, Cultural Studies and Linguistics.

However, the focus was to move from the investigation of the individual's mind to the analysis of the expression or representation of the self within the context in which it was inserted (GERGEN, 2000). We find, for example, in Oyserman et al. that, "the identities constituting the self are dynamically constructed in context (2012, p. 70)."3 It follows that scholars set out to study the subject's social relations, favoring the way the expressed themselves to construct and be constructed in their social interactions. Perspective, this way, meant firstly realizing the existence of the other, against which individuals started to see themselves. That is what Bakhtin, for example, defended. He postulated that the other is the "constituent of the 'I'" (1997, p. 47), although the latter is not seen as a mere object of the construction and analysis by the former, but rather a co-participant in a 'symmetric' relation, i.e., a 'dialogical' relation in which neither of the parts has authorship of the discourse. The same idea is defended by Lemos, who says that "we do not grasp the object apart from its relation with the subject as much as we do not understand the subject out of its relation with the world" (2013, p. 54)4.

Later on, research in the field of identity (BANKS, 2015; OYSERMAN et al, 2012; PAPACHARISSI, 2011, to mention some) led to a broader view of what might entail the self, that is, a move from the concept of a single body that encapsulated a self, ready to be manifested, towards the acceptance of a number of other participants, material or not, which interacted in the discourse activity to make the self fluid. This plurality, therefore, makes reference to "not just a single me but multiple me's, or facets to each me" (OYSERMAN et al, 2012, p. 72) ${ }^{5}$. The authors argue that since the self is a meaning-making tool, then it should be sensitive to context, that is, new information, and, thus, malleable and variant across changes in the features of both the external and internal worlds. Such broader view, thus, sets the foundation to what is known as the ActorNetwork Theory (ANT). In sum, network, as it is defined by ANT, is not infrastructure, but that which is produced out of the relationship between humans and non-humans. It is a dynamic concept. It is not what connects, but what results from the connections. There's no essentialism, but emergent relationships (LEMOS, 2013).

Such considerations are an effective entry to the present study, which addresses the self within the context of the postmodern times, or 'late modernity' (GIDDENS, 1991). According to Giddens, lifestyles are characteristically attached to specific contexts of action which also express themselves. Hence the idea of an evolving self

\footnotetext{
3 “as identidades que constituem o eu sâo dinamicamente construídas no contexto (minha traduçâo).

4 náo reconhecemos o objeto fora de sua relaçáo com o sujeito, assim como náo entendemos o sujeito fora de sua relaçấo com o mundo (minha traduçấo).

5 năo há somente um eu, mas múltiplos eus ou facetas de cada eu" (minha traduçâo).
} 
(PAPACHARISSI, 2011), encompassing not only the various contexts presented to the subject but also the diversity of electronic media and physical objects to be used in the expression of the self.

The approach adopted here draws on Banks's multimodal model (2015), which treats the self as being itself a network. Such stance makes us look deeper into the notions of space and time across digital and physical contexts. To make it clearer, space is used in conformity with the second definition in Lemos, where it is described "not as a place a priori, but as a network of associations between places and objects. It's dynamic and infinite and results out of the relations between the things constructed" (2013, p. 53)6. Precisely, we aim to answer the question posed by Banks of "how the mundane objects of everyday physical and digital life contribute to the emergence of the self" (2015, p. 2) - by investigating the way the self is constructed in Zach Gross 's video of two ballerinas performing a scene of Tchaikovsky's opera Onegin, based on the Russian writer Pushkin's classical literary work. It 's a $19^{\text {th }}$ century novel written in verse rather than prose, which narrates the story of Tatyana 's love for Onegin and also provides the reader with a detailed view of the Russian life in St. Petersburg at the time. Lachmann (2011) refers to Pushkin's work as a threshold during the time of its canonization. The novel in verse, published in serial form between 1825 and 1832, was marked by innovation and a sharp break with tradition, becoming a text that divided Russian literature 'before' and 'after' Onegin. It has been called by Contemporary Criticism an encyclopedia of Russian Society.

Borrowing from Banks that "the self is a subjectively experienced assemblage of identities that are likewise complex collections of objects networked across spaces" (2015, p. 2) ${ }^{7}$, we focus on this interweave of objects across different spaces in the physical world. In our case, specifically, the semiotic elements are - the dance, the wardrobe, the music, and the image - that make up the representation of the main female character, performing a scene of the opera. The video comes as a good example of Lévi-Strauss' explanation of the association between images and concepts, where he asserts that, "signs resemble images in being concrete entities but they resemble concepts in their powers of reference" (1996, p. 18). ${ }^{8}$ This is what the present study aims at: identifying the concepts represented in the association of the many signs in the ballerinas video, which come together in the construction of the Self.

Such combination of media is referred to in Woolf (1999, p.37) as intermediality (my italics). He says that the term can be defined as the direct or indirect participation of two or more media in the signification of a human artefact. His study, like the present one, which started with the Russian writer Pushkin's lyric poem Onegin, and was later made into an opera by the famous, also Russian, composer Tchaikovsky, focuses on the relationships between literature and other arts, more precisely, the 'musicalization of fiction' (p.3 - commas in the original). According to Woolf, this has been a natural

6 náo como um local a priori, mas como uma cadeia de associaçôes entre lugares e objetos. É dinâmico e resulta das relaçóes entre aquilo que foi construído (minha traduçâo)

7 "o eu é um conjunto de identidades subjetivamente experienciadas, que sâo também uma complexa coleçâo de objetos encadeados através dos espaços (minha traduçâo).

8 "signos assemelham-se a imagens enquanto entidades concretas, mas lembram conceitos no que diz respeito a seus poderes de referência (minha traduçăo). 
combination since the times of Aristotle's ut picture poesis in ancient Greece (WOOLF, 1999). At a more recent past, however, we have, for example, the opera, considered a form of multi-media art due to its very nature. Music and poetry are, thus, considered 'sister arts' for the common characteristics that entail, namely sound, melody and rhythm (WOOLF, 1999, p3). In Onegin, for instance, these features are mirrored by the iambic tetrameter verses, which make up the lyric narrative.

Now, as the main objective of this study is to deal with the elements networked in the ballet video - Bring in the ballerinas - made by Zach Gross, an American photographer, which presents two dancers staging two moments of Onegin, a word on the relationship between these two arts, ballet and literature - is very appropriate. Marcsek-Fuchs approaches the theme by saying that dance and literature, though appearing to be media antagonists as the former is kinetic and the latter static, have a lot in common. They can tell a story and express emotions; they are 'part of a culture, represent a culture and subvert a culture' (2015, p.1). By discussing how dance is represented in literature, she uses the term leporello to "indicate the effect that a single word in the text evokes several kinetic and cultural implications in the recipient" (MARCSEK-FUCHS, 2015, p.5).

Although in our study the reverse is what is brought under discussion, that is, the dance representing the text, the same metaphor can be used, for it is correct to assume that Onegin, in its lyricism has evoked feelings that had Tchaikovsky translate into an opera. As for the channels that can be used to represent dance, Marcsek-Fuchs raises the question whether the body would be the one only to convey meaning or should we take into consideration the movement patterns and the music the accompanies it, if the case, as part of a multichannel medium (MARCSEK-FUCKS, 2015, p.12). In this respect, Wolf's specification of the term medium seem to fit better our purpose here. He defends that it is "specified not only by particular channels (or one channel) of communication but also by the use of one or more semiotic systems serving for the transmission of cultural 'messages'"' (WOLF, 1999, p.35)10. Another scholar, Clüver (2007), affirms that most texts are completely intermedial and interactive, being instantly transmitted to receivers all over the globe, being designed to invite the participation of a global community.

Having set the picture in which the present study is framed, in the next section we briefly debate the concepts of space, time and identity in the postmodernity, which are the cornerstones of the analysis.

\section{Space, Time and Identity - From Giddens to Lyotard}

One of the many authors who have addressed the issue of identity construction in the modern times is Anthony Giddens (1991). Giddens differs modernity from any other previous era by characterizing it as being far more dynamic and profound. He claims that modernity affects human behavior and consequently social practices like no other system before. Three factors are considered crucial in its entailment. Firstly, Giddens

9 indicar o efeito que uma única palavra no texto evoca várias implicaçóes cinéticas e culturais no leitor (minha traduçâo).

10 "especificado nâo apenas por canais específicos (ou um canal) de comunicaçāo, mas também através de um ou mais sistemas semióticos que servem à transmissăo de mensagens culturais (minha traduçâo). 
recognizes a distinct relation between time and space, where these two are separated yet at the same time reconnected, though not by the mediation of place. Rather, the cutting off of time from space "provides the very basis for their recombination in ways that coordinate social activities without necessary reference to the particularities of place" (GIDDENS, 1991, p.16-17)11. The video analysed here, produced by Zach Gross, is a very good example of how people can reconnect with Pushkin's novel through a completely different medium and at any time they deem appropriate. Such consideration of space and time takes us to the second main factor to contribute to a totally unprecedented social practice seen in modernity: the disconnection of social relations from local contexts, what Giddens calls disembedding (1991, p.17). He points out two disembedding mechanisms, namely symbolic tokens, whose primary representative is money - since it is a means of credit and thus brackets time and allows transactions between people who have never met one another physically, this way bracketing space - and expert systems (GIDDENS, 1991, p.18). The latter "bracket time and space through deploying modes of technical knowledge, which have validity independent of the practitioners and clients that make use of them" (GIDDENS, 1991, p.18) ${ }^{12}$. Once again, to illustrate Giddens's second factor, we turn to our video. Relations developed in the technological era differ from the pre-modern times by means of technology. The broad public can have access to Pushkin's work online, be it through the New Yorker magazine or the video.

As it may be observed, the change of time and space, coupled with the disembedding mechanisms, in Giddens's words "propel social life away from the hold of pre-established precepts and practices" (GIDDENS, 1991, p. 20). Lastly, the third major factor of influence on the dynamism of modernity is reflexivity. Unlike its definition as human being's intrinsic reflexive monitoring action over activities carried out, the term here refers to the "susceptibility of most aspects of social activity, and material relations with nature, to chronic revision in the light of new information or knowledge"13 In the present study this can be recognized in the new reading of Tchaikovsky's opera carried out by the South African choreographer Cranko. He not only reshaped it into a three-act piece only, but also decided to use a rearranged version of Tchaikovsky's composition instead of using the original composition. In other words, the application of organized knowledge to social life circumstances in order to organize and transform them.

Following all these advancements witnessed throughout Gidden 's modernity, the technological revolution in the last century paved the way to further changes that would reshape people's lives regardless of ethnicity, geography or religious beliefs, a time that came to be known as postmodernity. The term used here adopts the views defended in Lyotard (1984), where the author recognizes that postmodernity involves a rupture with the previous dominant culture and aesthetic; a different socioeconomical e social moments. Thus, globalization, despite its diverse effects, was an unavoidable

11 "propicia a própria base para sua recombinaçâo em formas que coordenam atividades sociais sem necessariamente referir-se às particularidades do lugar (minha traduçâo).

12 "agrupa tempo e espaço por meio de opçóes de conhecimento técnico, o qual tem validade independente dos seus usuários (minha traduçâo).

13 suscetibilidade da maioria dos aspectos da atividade social, e relaçôes materiais com a natureza, a revisấo crônica à luz de novas informaçôes ou conhecimento (minha traduçâo). 
ending of a process that had the Internet as one of its main protagonists. While, on the one hand, the political and social movements etched their hallmarks in History, being the fall of the Berlin Wall, the dissolution of the Soviet Union and the European Unification good examples, on the other hand the Internet, in the postmodernity, played its role by speeding up the breakdown of all boundaries between nations. The space-time relation was totally redefined in the cyberculture. Giddens argues that Globalization points to the intersection between presence and absence, the weaving of social events and relations at a distance with local contextualities (GIDDENS, 1991). The intentioned consequence was a complete change in the systems of information, communication, economy and social relations. The immediate and limitless access to a never-ending array of options made the virtual world as real as the physical world, with its own systems and rules.

Many and similar are the approaches to the new situation that was established: While Giddens (1991) specifies the three characteristics above, Haesbaert defines postmodernity as

an arbitrary gap in the linear view of time. Firstly, changing history through completely radical proposals, postmodernity would surely, though later, do the same with geography. Spaces succumbed as a result of time change, as people saw themselves immersed in relations at speeds never seen before, or, rather, in real time (HAESBAERT, 2002, p. 29-30). ${ }^{14}$

He explains that the dissociation of time and space, coined as deterritorialization, is necessarily followed by a process of definition of new territories, a term which, in his view, has a tripartite interpretation: physical, political, and provided with identity (HAESBAERT, 2002, p. 37). He also defends that the central aspect underlying the definition of territory is the controlling character of the social processes it implies, not limiting the reference exclusively to political and economic control, but, above all, to the cohesion power of identities.

This concept echoes Giddens' theory that separation of time and space sets up the very basis for their recombination in order to reorganize the social aspects of life.

This process of deterritorialization changed the way people saw themselves, leading to a sense of homelessness and identity, despite presenting them with the options of new identities, virtual realities. As a result, individuals had to learn how to adapt to this new environment and to (re)create themselves by taking on new identities. And last but not least, they were faced with the problem of representing this new self. With so many options provided by technology and the new social contexts, people began to get confused by the various stances taken in each context. Giddens (1991) draws our attention to the fact that the answer to a very simple question or the reaction to the commonest inquire demands that the individual put in parentheses a potentially almost infinite array of possibilities. Still, "what makes a reply 'adequate' or 'acceptable'

14 “Um corte arbitrário numa visăo linear do tempo. Primeiramente, ao mudar a História por meio de propostas completamente radicais, a pós-modernidade faria o mesmo, ainda que mais tarde, com a geografia. Espaços sucumbem em resultado da mudança de tempo, à medida em que as pessoas se veem imersas em relaçóes de velocidade nunca vistas, ou melhor, em tempo real (minha traduçăo). 
requires an indescribable shared referent of reality" (GIDDENS 1991, p.43) ${ }^{15}$. The individual is now faced with a totally different notion of space, as he engages socially through a private media environment "by utilizing existing and imagined geographies of space" (PAPACHARISSI 2011, p. 306) ${ }^{16}$.

Addressing the matter of identity amid what Lyotard denominates 'crisis of representation', that is, "an essentially realistic epistemology, which conceives of representation as the reproduction, for subjectivity, of an objectivity that lies outside it" (LYOTARD, 1984, p. viii)17. Castells distinguishes between "roles and identities". The former, he says, is defined by norms structured by social institutions and organizations, while identities are meaning sources for the individuals themselves, being constructed by the subjects through an individuation process (CASTELLS, 2008, p. 22-23). However, no self is an island, rather, each self exists "in a fabric of relations that is now more complex and mobile than ever before" (LYOTARD 1984, p.15). Both ideas can be related by saying that "self-identity in public or private life traverses distinct yet connected planes of interaction or networks" (PAPACHARISSI 2011, p.304). To Gergen, in postmodernity, the individual finds himself in a state of continuous constructions and reconstruction (GERGEN, 2002). This led to a number of studies about the means used by men to represent themselves in the diversity of contexts they were part of. We are, then, faced with the task of looking into some of the studies of identity representation, to pave the way pursued in the present article.

\section{REPRESENTATION OF THE SELF}

Identity, as defined in Oyserman et al, is "orienting, providing a meaning-making lens and drawing one's attention to specific features of the immediate context"18 (OYSERMAN, 2012, p.69). Therefore, wholeness is achieved by the association of the various personae, or identities, as defended by the authors: "together, identities make up one's self-concept - variously described as what comes to mind when one thinks of oneself" (OYSERMAN et al 2012, p.69). In different words, the various elementary selves that constitute, or are organized into, a complete self are the various aspects of the structure of that complete self answering to the various aspects of the structure of the social process as a whole (MEAD 1934, p. 67). Gubrium and Holstein point out a similar view, when they say that the self is polysemic, i.e., "attached to, and articulated with, multiple systems of signs (GUBRIUM \& HOLSTEIN, 1994, p.685)." Symbolization, in the construction of meaning, "constitutes objects not constituted before, objects which would not exist except for the context of social relationships wherein symbolization occurs" (MEAD 1934, p.38). Mead still reminds us that the social process, as involving communication, is in a sense responsible for the appearance of new objects

15 'uma resposta se torna 'adequada' ou 'aceitável dependendo do quanto partilhamos o referencial de realidade (minha traduçăo).

16 “ao utilizar as geografias de espaço existente e imaginadas (minha traduçăo).

17 uma epistemologia essencialmente realística, a qual concebe a representaçăo como reproduçăo de um objeto, no caso da subjetividade, que reside fora dela (minha traduçáo).

18 direcional, propiciando uma lente que cria sentido e chamando atençâo para as características específicas do contexto imediato (minha traduçăo). 
in the field of experience of the individual organisms implicated in that process.

One other aspect that we must get back to in the process of representation of the self is the aforementioned Gidden's "reflexivity of the self". This reflexivity is directly connected with knowledge that presupposes consideration of risks inherent to postmodernity. Also, as a result of this reflexivity, the body is affected to the point of becoming less and less "extrinsic, 'given', functioning outside the internally referential systems of modernity, becoming itself reflexively mobilized" (GIDDENS 1991, p.19). This is the case in Zach Gross's video, a conscious knowledge of how the body in the flowing of the dance can create an intended trait of personality out of the relation between body and all the other semiotic signs that make up the scene, skillfully constructed by the special effects made possible by technology. In this respect, Mead postulates that

reflection or reflective behavior arises only under the conditions of selfconsciousness, and makes possible the purposive control and organization by the individual organism of its conduct with reference to its social and physical environment, i.e., with reference to the various social and physical situations in which it becomes involved and to which it reacts (MEAD, 1934, p. 44).19

The socialization process, in which the construction of the self takes place through reflexivity and knowledge of options and risks involved, is the public environment used to authenticate identity and introduce the self through the reflexive process of fluid association with social circles. "Individual and collective identities are simultaneously presented and promoted" (PAPACHARISSI 2011, p. 304). The self becomes the assemblage of the many identities resulting from the actors' material-semiotic interactions.

In our study, based on Cranko 's three-piece adaptation of Tchaikovsky's opera, these relations and the perception of the public reality are constructed through the actors' consciousness of their own bodies, along with their interactions with the other theatrical elements. In his seminal work The Primacy of Perception (1964), MerleauPonty discourses about the body being wholly animated and having all its functions contribute to the perception of objects. He advocates that we perceive external space through our bodily situation. In his words, "a corporeal or postural schema gives us at every moment a global, practical, and implicit notion of the relation between our body and things"20 (p.5). This can be seen in the pas de deux performance of Onegin, where the bodies, in their flowing movements, show awareness of their relations to one another and to the things that make up the whole textual scene. Our body does not 'belong' (my inverted commas) to space. We transport it as if by magic; it is ours and through it we have access to space. It 's more than an instrument. It 's our perception of the world, the visible form of our intentions (MERLEAU-PONTY, 1964, p. 5).

19 reflexăo ou comportamento reflexivo surge somente nas condiçôes de autoconsciência, possibilitando o controle e a organizaçăo propositais, por parte do organismo individual, de sua conduta com referência ao seu ambiente social e físico, isto é, com referência às várias situaçōes sociais e físicas nas quais ele se envolve e às quais ele reage (minha traduçáo).

20 um esquema corpóreo ou postural nos permite a cada instante uma noçáo global, prática, e implícita da relaçăo entre nosso corpo e as coisas (minha traduçâo). 


\section{THE ACTOR-NETWORK THEORY (ANT)}

Network as it is understood in the ANT does not take the postmodern meaning used in computer science; rather, it is the resulting shape from the association of material-semiotic relations between objects, which, depending on the way they cluster together, shall determine the nature of the self. The self, then, loses its position as the node of the relation to become a network itself. It relies on the (re)arrangement of all the objects in the semiotic relation since the body, once considered to be the host of the self, becomes just one among many systems (BANKS, 2015; LEMOS, 2013).

Banks presents "three primary multiplicities of the self": (i) multimodality - which entails operationalizations that go beyond the grounding of the self in a physical body, understanding the self to be the outcome of the association of many different objects not necessarily directly associated with the human body; (ii) multiplexity - the various meanings carried by the objects in their complex associations. In other words, the self is a network of many different kinds of things; (iii) multispatiality - the articulation of the self across many different spaces (BANKS, 2015, p.4).

To understand the self as a network of networks, we have to consider the relation between objects, material and immaterial. In the case of a ballet performance, we need to consider "the collaborative efforts of a stage director and set, lighting, costume designers, conductor, choreographer, and the performers themselves" (Clüver, 2007, p. 29-30 ${ }^{21}$. Still, according to the author, medium has many meanings, several of which can account for intermediality. Physical media, for instance, are the means where complex signs are produced, such as instruments, video camera, voice, the body, etc. Corresponding media employing the physical ones are dance, music, video, speech, etc. Lastly, there are the public media, which includes the traditional print media and those that depend on more complex technology.

The standpoints presented above by Banks (2015), Clüver (2007), and MerleauPonty (1964) set, thus, the path to our analysis of the mentioned Zach Gross's video, in which we search to examine the various particularities that lie behind the protagonists' reconstruction of their characters' identities.

\section{ONEGIN - FROM CLASSICAL NOVEL TO MODERN BALLET}

Aleksander Pushkin's Eugene Onegin "is considered Pushkin's most outstanding and characteristic work" (MAZENNO, 2010). One of the most intriguing elements of Pushkin's work is its characterization as a piece of verse rather than prose, though the plot may sometimes be read as a work of prose. Written over a seven-year period between 1823 and 1830, it was published as a series from 1825 to 1832, and first appeared as a complete book in 1833. The work varies in tone and texture ranging from youthful sprees to darker passages on disappointment, betrayal, and a pointless, wasted life. One of the main plots in Onegin is the relationship between the two main characters, Tatyana and Onegin, a relationship that serves as an important characterization

21 os esforços colaborativos de um diretor de palco e cenário, iluminaçăo, figurinistas, maestro, coreógrafo, e os próprios dançarinos (minha traduçāo). 
of both figures. A rich man from St. Petersburg, Onegin inherits his uncle's estate and moves to the country, where he languishes in boredom, breaks the heart of a young, romantic Tatyana, and kills his best friend Lensky in a classic Romantic duel, over jealousy of Olga, his fiancée. After this unintended tragedy he leaves town for an extended period of time. In his absence the young girl, Tatyana, proves herself to be a character of significantly greater depth: she is sent to Moscow to find a husband on "marriage mart," and after making brilliant match she is transformed into a high society lioness; however, her greatest desire is to return to the simple country life, which is now forever behind her. Predictably, when Onegin returns to St. Petersburg some years later, he falls hopelessly in love with the gracious, but impenetrable, Tatyana. Her pledge of eternal fidelity to her husband only heightens the misfortune of missed opportunity and love lost due to poor timing. Onegin is, in sum, a novel in verse about the inner and outer worlds of its characters. About the real and the imaginary, and the intimate. With Onegin Pushkin writes a genuine "encyclopedia of Russian life," offering an authentic portrayal of early 19th-century life in St Petersburg, Moscow and the Russian provinces. It was in part this "Russianness" that attracted Tchaikovsky almost half a century later (TVERITINA, 2013).

The story was first admired by the classical Russian master Tchaikovsky when he came across Pushkin's work in 1877. At that time the composer had received a love letter form a former student, Antonina Milyukova, and decided not to echo Onegin's behavior, which led him to marry Milyukova. Due to the homosexual nature of his character, the union hardly survived the first three months, but it had been enough for the Russian master to compose Onegin in the wake of his relationship. Its debut took place in 1879 at the Maly Theater in Moscow, with a grander and more accomplished version premiered at the Bolshoi Theater in Moscow. In the same way Eugene Onegin adapted various Western European literary styles, most notably the concept of the Byronic Hero, Tchaikovsky transformed Western European operatic forms into a distinctly Russian piece of instrumentation and performance.

One century later, the South African choreographer Cranko discovers Pushkin's novel while he was choreographing the dances for Tchaikovsky's opera of the same name in 1952. He produced a three-act ballet, premiered at Germany's Sttutgart Ballet in 1965, when he, then, preferred to have Kurt-Heinz Stolze arrange Tchaikovsky's composition rather than to use the Russian composer's original work. This was just one of the changes that Cranko would make to the original story, which would get him mixed reviews. One such personal touch is his reading of Tatyana's raspberry-colored beret as a red dress worn in her duet with Onegin. Yet, Cranko's technical talent and geniality in translating feeling and detail into theatrical symbols is revealed in acts I and III, the most important ones.

At this point, we find it important to briefly discuss the process of multi-mediality, or when and how a medium is translated into other media. Marcsek-Fuchs questions whether this multi-mediality takes place at the moment one artifact set down in one specific medium is transported into or combined with another one, or when such possibility is conceived as a thought (MARCSEK-FUCHS, 2015, p. 2). Bearing in mind that the reader of a literary medium might fan out the written word into its multi-modality, she would assume that "even the seemingly mono-medial novel on the page is multimedial" (p.2). 
According to Straumann, poststructuralist notions of intertextuality set forth that "any text is in dialogue with a multiplicity of other texts. (STRAUMANN, 2015, p. 250)" Adaptations, she claims, refigure earlier adaptations, and despite deriving from previous texts they are not to be considered 'derivative or second-rate' (p. 250). Actually, we recognize that any new reading or revisiting of a text sheds light on new aspects that make it different and original in its interpretation. Straumann points out that to adapt means "to make suitable for a new purpose or to a different context" (STRAUMANN, 2015, p.251). In our study, Cranko's adaptation comes as such a reconsideration of Pushkin's and Tchaikovsky's (itself an adaptation of the literary work) works. The changes made by Cranko aim to give a more modern picture of the classical literature and musical composition. That can be explained by Cranko's shortening of the opera down to a three-piece work and choice of Stolze to rearrange the composition. Thus, we can see that since Pushkin's original novel, which was itself a new reading of the traditional prosaic style at the time, as it was written as a poem, there have been three different readings to Gross's video. Here too, we have a combination of media, for the video was published in an online issue of a famous magazine, the New Yorker.

In the first Act Tatyana is writing a letter to Onegin when she falls asleep and dreams that she is dancing with her beloved. "The 19th-century device of a mirror dance is the happy conceit: Tatyana dances with a double who portrays her reflection in a mirror frame, and Onegin steps in from this frame" (KISSELGOFF, 2001). In Act III, in its turn, the mature Tatyana, now married and loyal to her husband, tears up Onegin's letter, groveling at her feet and clinging to her body in a desperate duet.

These are precisely the Acts portrayed by Zach Gross's in his video at the Metropolitan Opera House, which we detail in the next section.

\section{ZACH GROSS'S VIDEO - BRING IN THE BALLERINAS}

Gross is an American photographer with works featured in The New Yorker (TNY), CNN, The New York Times, Flaunt, and Vogue, among others. While photographing for Joan Acocella's piece of the same name in The New Yorker (see references), he decided to go back to the Metropolitan Opera House that same week to make the video Bring in the Ballerinas, starring two leading Russian ballet dancers - Diana Vishneva and Natalia Osipova - playing Pushkin's pivoting character, Tatyana, in two principal moments, as mentioned above. Both dancers started out in the Russian Ballet Academy, and after collecting top prizes they moved on to become two world leading dancers, acclaimed by every public they performed to. Vishneva was the principal dancer with both the prestigious Mariinsky Ballet and the American Ballet Theatre. She has received the Prix Benois de la Dance, and has, lately, joined the Honorary Board of Directors of the Russian Children's Welfare Society. Osipova is currently the principal dancer with the Royal Ballet in London. She started at the age of 8 and moved to the internationally respected Bolshoi Ballet when she was 18. She was named one of the "25 to Watch" by Dance Magazine in 2007, awarded the Prix Benois de la Dance in 2009. Gross explained to TNY that he's got a lot of interest in "... the movement that transitions past structure into new evolved ones." He sees dance as "inspirational for opening new and deeper ways of understanding" (ACOCELLA, 2012). 


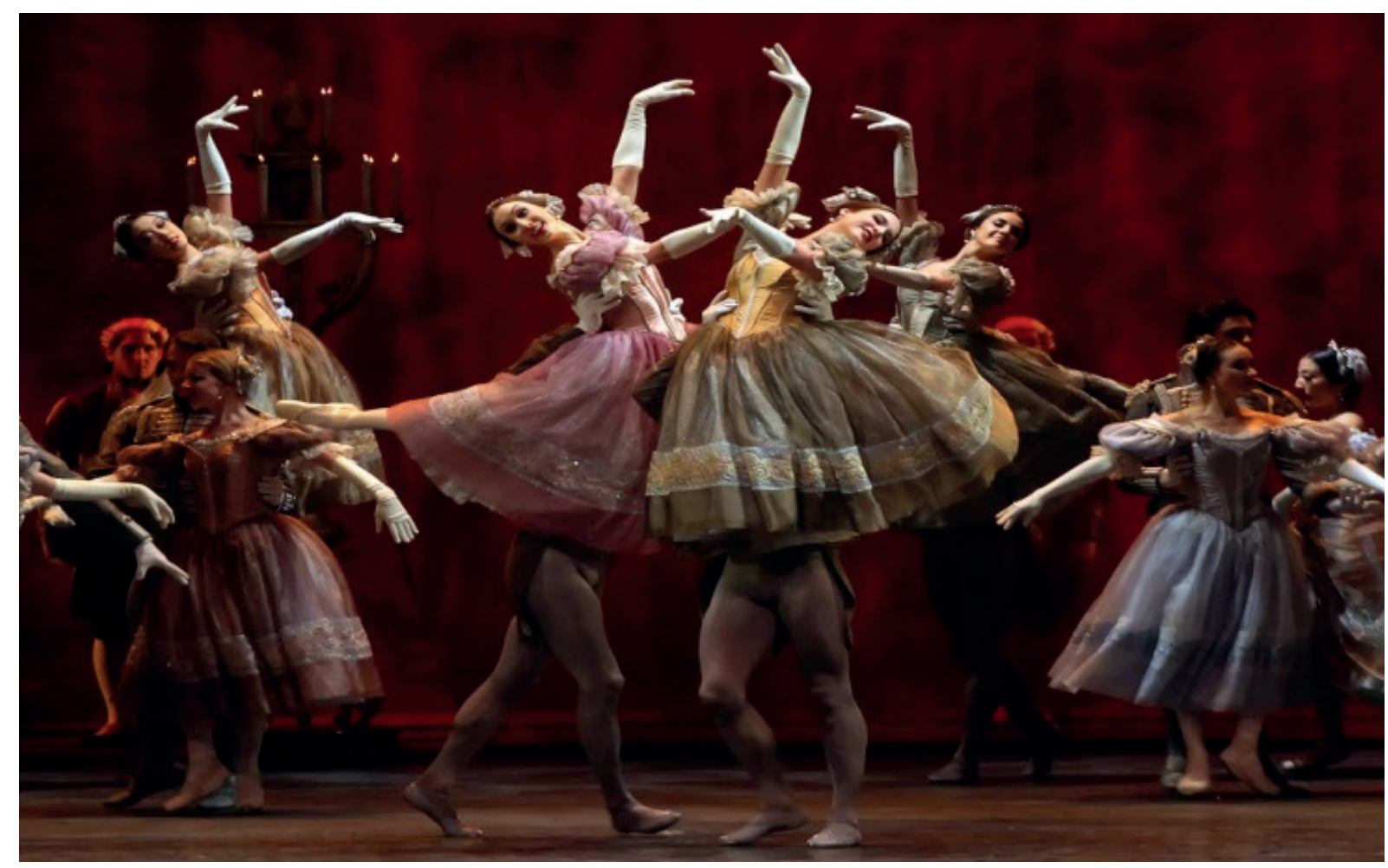

Figure 1. American Ballet Theater members in the work

Credit Andrea Mohin/The New York Times

Gross's video of the two Russian ballerinas dancing Onegin comes as a major semiotic example of how the self is made up of the various associations between elements such as body, space, situation, audience and an unlimited number of others. Developed by Banks (2015, p.4-5), this assumption entails the three already mentioned 'multiplicities' of the self: multimodality, multiplexity, and multispatiality. This intricate networked self is, in the words of Lévi-Strauss (1966, p.150), a 'bricolage'22, that is, "a system of paradigms constructed with the fragments of syntagmatic chains", or the use of the material at hand to create meanings.

22 A French term that refers to the assemblage of different parts to make an intended whole 


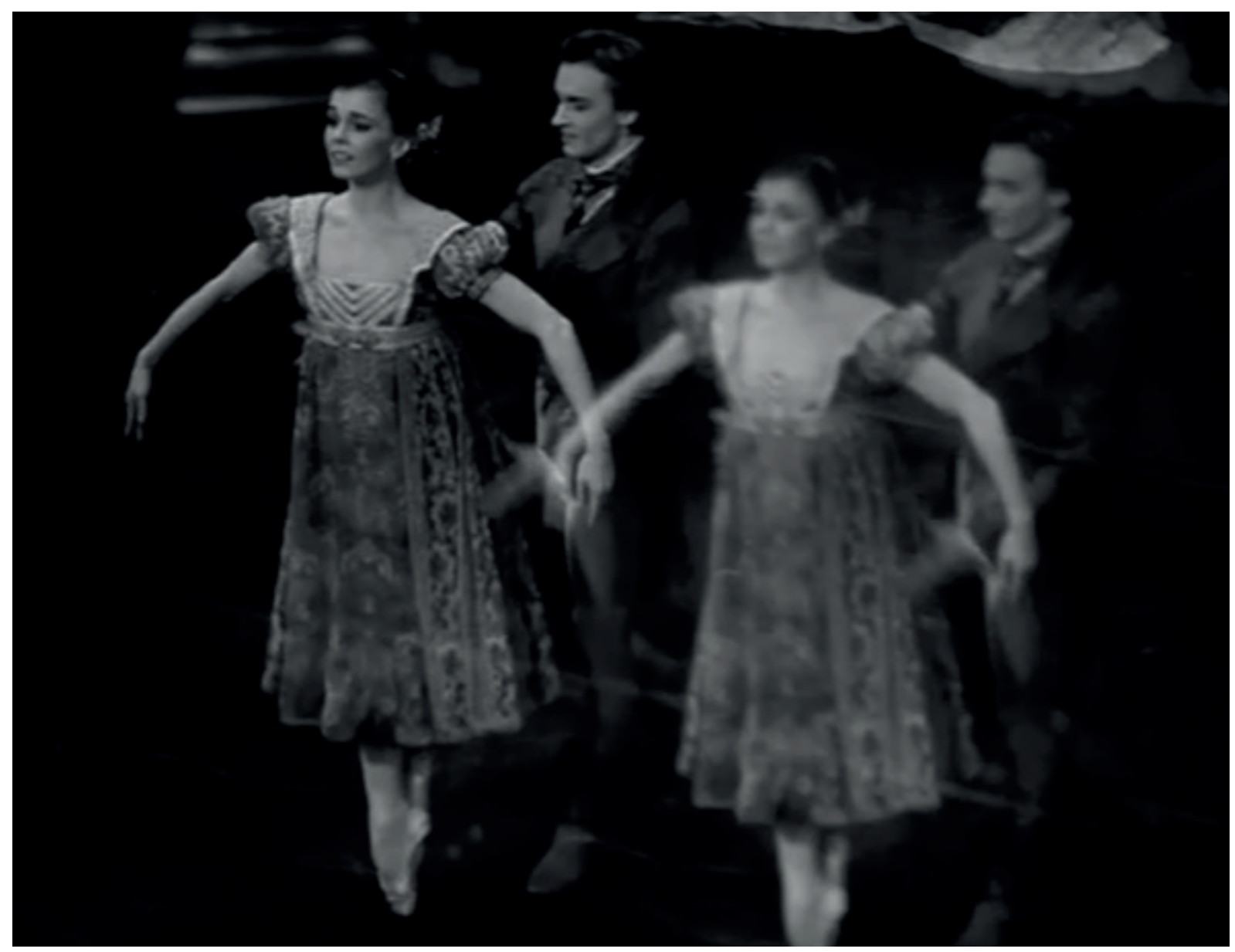

Figure 2. Metropolitan Opera House's performance of "Onegin."

Credit Zach Gross/The New York Times

Semiotically, we understand that the multimodal self is not limited to a body, but comprises different objects which may or may not bear a direct relation with it, being either material or immaterial, digital or physical. As for multiplexity, it addresses the complex relations between the many objects in the network, "carrying overlapping meanings and affiliations" (BANKS, 2015, p.4).

Finally, multispatiality is the third multiplicity presented by Banks to help shape the concept of self. As discussed above, technology has changed the way we used to understand space by redefining our ideas of territory, social context, and audience. L w explains that spaces are an expression of the possibility of pluralities and overlapping and reciprocal relations. In addition, the author says it "applies no less to territorial spaces than it does to the microspaces of everyday life" (L W 2008, p.26).

On the grounds of the theoretical postulations above, we now set about to look into the video more closely. For the purposes of the analysis, we focus on each of the multiplicities separately in regard to the video, although it's clear to us that the social contexts in which the subjects take part and within which they construct their different selves in a dialectical relationship are considered as a whole. 
As mentioned above, Gross's video comprises the dances performed in Acts I and III. In the second scene of Act I, Tatyana, depicted by Pushkin as a light-hearted, romantic girl, dreams of Onegin coming out of the mirror, where she had believed to see his admiring look, and getting into her world. The scene is represented by Tatyana and Onegin dancing the famous "mirror Pas de Deux". In the second scene of Act III many years had gone by before Tatyana and Onegin met again. This time, once again in her room, now a married woman, it is Onegin's turn to declare his love for her and beg her for love, with no success as she remains loyal to her husband. The grand finale is once again the two of them in a pas de Deux.

In terms of multimodality, we start with the book itself, moving to the opera, through the ballet to the video production. The video, object of our analysis, is made up of the orchestra and a piece of Tchaikovsky's music - played here in a more modern version - the dancers on stage against a black background, the ballerinas' dresses, and the couple's shaded image that splits up from the real pair, creating an onion skinning effect, adding to the movements performed by the deux: Jumps, flows, and leaps that are carefully executed so as to convey, in association with facial expressions and those elements already mentioned, the characters' selves. Material and immaterial media, therefore, play a crucial role in networking the self.

The relations sewn by these different modes of interaction lead us to the second multiplicity posed by Banks - multiplexity. Since the very opening, the video is all blurred and overlapped with shadowed and shaded images, giving the impression that the audience is placed afar as voyeurs, watching the orchestra members prepare for a rehearsal from behind a glass window. As the dancers appear on stage the onion skinning or ghosting effect takes the viewer through Pushkin's main theme - departure from reality towards fantasy, the fickleness between the real and the insubstantial.

The ballerina's white dress makes a semiotic reference to Tatyana's immaculate soul as an adolescent. Her naivety, purity and introspection, which cause her to be rejected by Onegin at first, are the main characteristics that build up her identity at this stage of life. The spiraling upward and rotational movements of the two ballet dancers along with the special effects that create shaded and shadowed figures all overlapped and blurred by a white-ghosted screen allow the viewer to wander back to the realms of Tatyana's dream.

Multispatiality, the third of the multiplicities, can be seen realized through the multimodal path to represent Onegin, that is, the timeline drawn from the book first published by Pushkin to the opera, the ballet and, finally, the video. Returning to L w's (2008) view that spaces are an expression of the possibility of pluralities and overlapping and reciprocal relations, we can think of the possibilities opened to the different audiences of the video due to its networked characteristics. The first and inherent boundary to be crossed by the self is that of the "personal and intimate" view held by the individual (GERGEN, 2000). "It is the ability to reflexively and subjectively experience this network of networks" (BANKS, 2015, p. 12). Gross's video allows the different viewers to identify themselves with the barrage of relations constructed in the video. As Ribeiro (2009, p.291) puts it, it is the possibility of exploring new existential, cognitive and experiential territories through the virtual world. Banks defends a similar point of view stating that human perceptions may be understood as 
an interplay between a human and some other object wherein the properties of each influence the meaning made (BANKS, 2015, p.6).

In light of this assumption, the internet becomes the virtual passport (RIBEIRO, 2009) to limitless spaces and possibilities out of which to construct the self. The relation viewer-virtual world dismisses the various cues needed in the face-to-face communication so as to foster understanding and association. Also, each viewer will identify himself with those aspects that might better contribute to (re)shape his identity. For example, to a ballet dancer the self to be constructed will come out of the interaction with the movements per se, while for those into the work of Pushkin and the art and literary world in general, the identity-networks may constitute the movements - now representing two pivotal moments of Pushkin's work- the music and the shaded blurred screen, which come to add to the artistic dimension of the self. In this case, Banks (2015, p.12) distinguishes this relation between human body and virtual semiotic items as the Self being phenomenologically divorced from the physical body. She says that "when objects and object-relations in the Self-network are perceived and considered, a sense of the Self-network emerges on two levels - one momentary and contextual, and the other enduring and cumulative. Lastly, Giddens claims

\begin{abstract}
the traditional connection between 'physical setting' and 'social situation' (inverted commas in the original) has been undermined, as mediated social situations construct new communalities - and differences - between preconstituted forms of social experience (GIDDENS, 1991, p. 84).
\end{abstract}

As we understand from the points aforementioned, postmodernity has witnessed a turnabout in the ways social relations are weaved in the world. Alongside the reshaping of traditional concepts such as time and space, what comes to be known as self goes beyond the absolute predefined thing limited by the body, to entail the very networks resulting from the various associations between material and non-material objects. The possibility of reaching online spaces gives the public a much broader access to other settings which trespass the threshold of the physical world, resulting in very different social experiences as compared to those in the last century.

\title{
6 CONCLUSIONS
}

The present study aimed to discuss the construction of the self by means of a different perspective from that traditionally adopted in the fields of Psychology, Cultural Studies, and Sociology - the actor-network theory (ANT). Unlike the theories that defend the notion of self as being body-bound, while at the same time it puts the right value on the body, ANT states that the self is built up through the agency of human and non-human actors. Moreover, ANT is not about any previously established social framework or context of action, though it recognizes the essentiality of social interactions so that "actors can constantly make meanings out of their agencies, mapping out the 'social context' in which they are placed" (LATOUR, 2005, p. 32). The same position can be seen in Gergen (1999), who defends that the individual action derives its sense or meaning from its placement within the extended interchange and Ribeiro (2009), whose point of view is that the occurrence of social exchanges is the main source for promoting the existence of virtual identity. 
This evolving construction of one's identities (PAPACHARISSI, 2011) through social interactions leads to unlimited possibilities if we consider the vast range of material and immaterial objects or actors involved in the process. So, in an effort to address the question of how the mundane objects of everyday physical and digital life contribute to the emergence of the self - we undertook the task by presenting how Pushkin's main female character in Onegin - Tatyana - is depicted in Zack Gross's video Bring in the Ballerinas, by focusing on the different kinds of interactions between the various elements, or objects that make up the video.

Socialization is inherent in the human being, as they feel that they should belong in a group where they can recognize themselves and be recognized as individuals. Whether physically or virtually, the subject is appealed to perform in order to unmask themselves, take off the identities that were formed out of their different, assumed roles in society. Performance is centered on public displays of social connections or friends, used to validate identity and introduce the self through the reflexive process of fluid association with social circles. As a deduction, "individual and collective identities are simultaneously presented and promoted" (PAPACHARISSI 2011, p. 305).

We demonstrated that the experience of constructing the self entails the three multi-aspects defined by Banks (2015) - multimodality, multiplexity, and multispatiality. These aspects had the body as just one among various other actors that authenticate the self, namely the music, the special effects, the dance, the dress and the relations between the subjects and the internet which were used to access the referred video. In other words, that is what was claimed by Lefebvre

\begin{abstract}
spaces of representation' stand for spaces of expression, conveyed by images and symbols, which complement spatial practices and cognition. It is this aspect of space that can undermine prevailing orders and discourses and envision other spaces. It is often the refractory spaces of artists or mythical, premodern images of space that call given societal conditions into question (LEFEBVRE, 1991 cited by L W, 2008, p.28). ${ }^{23}$
\end{abstract}

In sum, the present paper aimed to introduce the reader to another way of conceiving the individual's role in the postmodern society, where the ethos is regarded as a network of relations between different actors, physical and non-physical, instead of a preconceived being ensconced in the limits of the human body. 


\section{REFERENCES}

Acocella, J. (2012, June 25). Bring in the Ballerinas. Retrieved from https://www.newyorker.com/magazine/2012/06/25/bring-in-the-ballerinas.

Bahktin, M. (1997). Estética da Criaçāo Verbal. Săo Paulo: Martins Fontes.

Banks, J. (2015, October). Multimodal, multiplex, multispatial: A network model of the self. New Media \& Psychology, 19(3), 1-20.

Bruner, J.(1994). The"remembered" self.InNeisser,U.; Fivush, R.(Eds.), The Remembering Self Construction and Accuracy in the Self-Narrative. (pp. 41-54) Cambridge: Cambridge University Press, Cambridge.

Clüver, C. (2007). Intermediality and Interarts Studies. In Arvidson, J., Askander, M., Bruhn, J., Führer, H. (Eds.), Changing Borders: Contemporary Positions in Intermediality. Intermedia Studies Press; Vol 1. Intermedia Studies Press, Lund. (pp.21-53).

Castells, M. (2008). O Poder da Identidade. Sāo Paulo: Paz e Terra S/A.

Gergen, K.J. (1999). Social Construction and the Transformation of Identity Politics. In Newman, F.; Holzman, L. (Eds.). End of Knowing: A Developmental Way of Learning. New York: Routledge.

Gergen, K.J. (2000). The Saturated Self: Dilemmas of Identity in Contemporary Life. USA: Basic Books.

Giddens, A. (1991). Modernity and Self-Identity:Self and Society in the Late Modern Age: Stanford: Stanford University Press.

Gross, Z. (2012, June 25). Bring in the Ballerinas [video file]. Retrieved from https:// thescene.com/watch/thenewyorker/bring-in-the-ballerinas.

Gross, Z. (2014, July 22). Metropolitan Opera House's performance of "Onegin." The New York Times. Retrieved from https://www.bing.com/search?q=natalia+osipova+diana+misheva +onegin\&qs=n\&sp=1\&pq=natalia+osipova+diana+misheva+onegin\&s$\mathrm{c}=036 \& \mathrm{sk}=$ \&cvid=51995AF0F7154 13BBE1273CB54A9492\&FORM=VDVVXX

Gubrium, J.F., \& Holstein J.A. (1994, November). Grounding the postmodern self. The Sociological Quarterly 35(4), 385-703.

Haesbaert, R. (2002). Fim dos terrritórios ou novas territorialidades? In Moita Lopes, L.P, \& Bastos, L. C. (Orgs.), Identidades: Recortes Multi e Interdiscipinares (pp. 29-51). Săo Paulo: Mercado das Letras. 
Kisselgoff, A. (2001, June 04). Dance Review: An American Flourish to Stuttgart's Signature. Retrieved from http://www.nytimes.com/2001/06/04/arts/dance-reviewan-american-flourish-to-stuttgart-s-signature.html.

Lachmann, R., \& Pettus, M. (2011) Alexander Pushkin's Novel in Verse, Eugene Onegin, and its Legacy in the Work of Vladimir Nabokov. Pushkin Review 14,1-33. Slavica Publishers. Retrieved from https://muse.jhu.edu/article/468251/summary\#info wrap.

Latour B. (2005). Reassembling the Social:An Introduction to Actor-Network Theory. New York: Oxford University Press.

Lemos, A. (2013, June). Espaço, mídia locativa e teoria ator-rede. Galáxia, 25, 52-65.

Lévi-Strauss, C. (1966). The Savage Mind. Chicago, IL.: University of Chicago Press.

L w, M. (2008, August). The Constitution of Space - The Structuration of Spaces Through the Simultaneity of Effect and Perception. European Journal of Social Theory 11(1), p.25-49.

Lyotard, J-F.(1984) The Postmodern Condition: A Report on Knowledge(Tls. G Bennington and B Massumi). Minneapolis, MN: University of Minnesota Press.

Marcsek-Fuchs, M. (2015). Dance and British Literature: An Intermedial Encounter (Theory-Typology-Case Studies). Amsterdam: Koninklijke Brill nv.

Mazzeno, L.W. (2010) (Ed.). Eugene Onegin - Critical Evaluation. eNotes. com, Inc. Retrieved from http://www.enotes.com/topics/eugene-onegin/ critical-essays ${ }^{\#}$ critical-essays-critical-evaluation.

Mead, G.H. Mind, Self, and Society. Chicago, IL: University Of Chicago Press, 1934.

Merleau-Ponty, M. (1964). The Primacy of Perception. Northwestern University Press: USA

Mohin, A. (2012, June 5). American Ballet Theater members in the work. The New York Times. Retrieved from https:/www.nytimes.com/2012/06/06/arts/dance/american-ballet-theater-in-onegin-at-metropolitan-opera-house.html

Oyserman, D.; Elmore, K.; Smith, G. (2012) Self, Self-Concept and Identity. In: Leary MR and Tangney JP (Eds.) Handbook of Self and Identity. New York: Guilford Press, p. 3-14.

Papacharissi, Z. (2011). Conclusion: A networked self. In Papacharissi, Z. (Ed.) A Networked Self: Identity, Community, and Culture on Social Network Sites. New York, NY: Routledge, p. 304-318, 2011.

Ribeiro, J.C. (2009). The increase of the experiences of the self through the practice of multiple virtual identities. PsychNology Journal, v.7 n.3, p.291-302.

Straumann, B. (2015). Adaptation - Remediation - Transmediality. In Rippl, G. (Ed.) Handbook of Intermediality - Literature - Image - Sound - Music. Berlin: De Gruyter. 
Turkle, S. (1995). Life on the Screen: Identity in the Age of the Internet. New York: Simon \& Schuster.

Tveritina, A. (2013, September 21) The Metropolitan Opera spreads Pushkin and Tchaikovsky around the World. Retrieved from https://www.rbth.com/literatu-

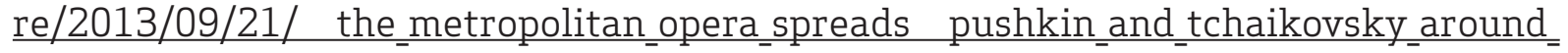
the world 30021.html.

Woof, W. (1999). The Musicalization of Fiction - A Study in the Theory and History of Intermediality. Amsterdam: Rodopi, B.V.. 